\title{
Pregnancy Among Women with Kidney Transplantation: A 20-Years Single-Center Registry
}

\section{Gravidez em transplantadas renais: registro de 20 anos de um centro de referência}

\author{
Stephanye Mariano ${ }^{1}$ Jose Paulo de Siqueira Guida ${ }^{1}$ Marcos Vinicius de Sousa ${ }^{2}$ \\ Mary Angela Parpinelli ${ }^{1}$ Fernanda Garanhani Surita ${ }^{1}$ Marilda Mazzali ${ }^{2}$ Maria Laura Costa ${ }^{1 \odot}$
}

${ }^{1}$ Departament of Tocogynecology, School of Medical Sciences, Universidade Estadual de Campinas, SP, Brazil

2 Renal Transplant Research Laboratory, Renal Transplant Unit, Division of Nephrology, School of Medical Sciences, Universidade Estadual de Campinas, SP, Campinas, Brazil

Rev Bras Ginecol Obstet 2019;41:419-424.

\author{
Address for correspondence Maria Laura Costa, MD, PhD, Rua \\ Tessália Vieira de Camargo, 126, Campinas, SP, 13083-887, Brazil \\ (e-mail: lauracosta.unicamp@gmail.com).
}

\begin{abstract}
Keywords

- kidney transplantation

- pregnancy

- high-risk

- hypertension

- premature birth

- dialysis

Objective To assess maternal and perinatal outcomes in pregnancies after kidney transplantation in a tertiary center in Brazil.

Methods Retrospective cohort of pregnancies in women with kidney transplantation at the Universidade Estadual de Campinas, from January 1995 until December 2017. Medical charts were reviewed, and maternal and perinatal outcomes were described as means and frequencies. Renal function and blood pressure were evaluated during pregnancy and postpartum.

Results A total of 22 women had at least 1 pregnancy during the considered time interval, and 3 of them had $>1$ pregnancy, totalizing 25 pregnancies. The mean age at transplantation was of $24.6 \pm 4.2$ years old, and the mean time interval until pregnancy was of $67.8 \pm 46.3$ months. The most frequent complication during pregnancy was hypertension, which affected 11 (64.7\%) women. The gestational age at delivery was $34.7 \pm 4$ weeks, and $47 \%$ of these pregnancies were preterm ( $<37$ weeks). A total of $88.2 \%$ of the women delivered by cesarean section. Renal function, measured by serum creatinine, remained stable during pregnancy, and the systolic blood pressure increased significantly, while the diastolic blood pressure did not differ during pregnancy.

Conclusion Pregnancy after kidney transplantation is a rare event. Pre-eclampsia and prematurity were frequent complications, and cesarean section rates were very high. A specialized antenatal and postpartum care with a multiprofessional approach and continuous monitoring of graft function are essential for the early diagnosis of complications and improved outcomes.
\end{abstract}

Resumo

Objetivo Avaliar os resultados maternos e perinatais de gestações em mulheres transplantadas renais em um centro terciário no Brasil.

(1) Maria Laura Costa's ORCID is https://orcid.org/0000-0001-8280-

3234.

received

December 9, 2018

accepted

April 4, 2019
DOI https://doi.org/

10.1055/s-0039-1688834.

ISSN 0100-7203.
Copyright @ 2019 by Thieme Revinter

Publicações Ltda, Rio de Janeiro, Brazil
License terms

(c) (i) 


\section{Palavras-chave}

- transplante renal

- gravidez de alto risco

- hipertensão

- parto prematuro

- diálise
Métodos Coorte retrospectiva de gestações entre mulheres transplantadas renais na Universidade Estadual de Campinas, de Janeiro de 1995 a Dezembro de 2017. Os prontuários médicos foram revisados, e os resultados maternos e perinatais foram descritos como médias e frequências. A função renal e a pressão arterial foram avaliadas durante a gravidez e o puerpério.

Resultados Um total de 22 mulheres tiveram ao menos 1 gravidez durante o período avaliado, e 3 delas tiveram $>1$ gestação, totalizado 25 gestações. A idade média no momento do transplante foi $24.6 \pm 4.2$ anos, e o tempo médio de intervalo até a gravidez foi de $67.8 \pm 46.3$ meses. A complicação mais frequente durante a gravidez foi a hipertensão, que acometeu 11 (64.7\%) mulheres. A idade gestacional no parto foi de $34.7 \pm 4$ semanas, e $47 \%$ das gestações encerraram-se prematuramente $(<37$ semanas). Um total de $88.2 \%$ das gestações terminou com uma cesárea. A função renal, avaliada pela creatinina sérica, permaneceu estável durante a gravidez, enquanto a pressão arterial sistólica aumentou significativamente. A pressão arterial diastólica não diferiu ao longo dos períodos avaliados.

Conclusão Gestação após o transplante renal é um evento raro. Pré-eclâmpsia e prematuridade foram as complicações mais frequentes, e as taxas de cesárea foram muito altas. O cuidado multiprofissional no pré-natal e no puerpério e a constante monitoração da função do enxerto são fundamentais para diagnosticar precocemente complicações e melhorar os resultados.

\section{Introduction}

The rise of hypertension and diabetes in recent years, along with other less prevalent causes, has increased the occurrence of chronic kidney disease (CKD), a progressive loss of renal function, classified in five stages, according to the glomerular filtration rate. ${ }^{1}$

The prevalence of CKD in Brazil is of 1.5\% and, currently, 3 to 6 million people live with this disease in the country, the majority of them untreated. In addition, there are $\sim 120$ thousand patients on dialysis, ${ }^{2}$ and $>92$ thousand people already underwent renal transplantation in the country. ${ }^{3}$

In advanced stages, CKD may impair fertility due to anovulatory cycles caused by hypothalamic-pituitary-axis dysfunction. ${ }^{4}$ Fertility can be restored after renal transplantation with the improvement of kidney function. ${ }^{5}$

Pregnancy after kidney transplant is associated with increased maternal and fetal complications. ${ }^{5}$ Obstetrics complications, such as hypertension, gestational diabetes mellitus, fetal growth restriction and preterm deliveries were observed in many previous studies. ${ }^{5-7}$ One fifth of pregnancies ends as abortion; however after the $1^{\text {st }}$ trimester, most pregnancies present adequate development. ${ }^{8}$

There is a lack of studies about renal and obstetrics outcomes in pregnancy after kidney transplantation. Knowledge about the topic is limited to a small number of cohort studies, most of them performed in high-income countries. ${ }^{9}$

The aim of the present study is to evaluate maternal and perinatal outcomes after kidney transplantation in a referral center in the southeast region of Brazil.

\section{Methods}

This is a retrospective cohort of all women followed at the Renal Transplant Unit of the Universidade Estadual de Campinas from January 1995 to December 2017. In the present analysis, we selected women who got pregnant after transplantation and had their antenatal care at the Women's Hospital of the same University. Both units are public tertiary health services that cover $\sim 5$ million people in the southeast region of Brazil. The medical charts of the women included in the present analysis were reviewed by researchers using a preapproved data collection tool. We collected data on sociodemographic characteristics, underlying cause of CKD, age at transplantation, time between the surgery and pregnancy, immunosuppressive therapy on pregnancy onset, and also graft loss after pregnancy. We also obtained data on obstetric characteristics, such as duration of pregnancy, occurrence of clinical complications (hypertensive diseases, diabetes), route of delivery, and postpartum infection. The perinatal outcomes evaluated were birthweight and Apgar Score at birth.

\section{Statistical Analyses}

Data were stored in Windows Excel 7 (Microsoft Corporation, Redmond, WA, USA) and analyzed with Epi Info 7 (Centers for Disease Control and Prevention, Atlanta, GA, USA). Data are presented in frequencies or means and standard deviation(SD).

\section{Ethical Approval}

The ethics board from the Universidade Estadual de Campinas approved the research protocol(CAAE 64490017.6.0000.5404), and individual consent was waived since this is a medical chart 
review. The present manuscript was written according to the strengthening the reporting of observational studies in epidemiology (STROBE) recommendations. ${ }^{10}$

\section{Results}

A total of 797 women with kidney transplantation were identified; of those, 494 were of reproductive age (18-49 years old) and had their medical charts reviewed. A total of 22 women had at least 1 pregnancy during the considered time interval, and 3 of them had $>1$ pregnancy, totalizing 25 pregnancies. Of those, six did not have their antenatal care at the Universidade Estadual de Campinas, and 19 were included in the present analysis. Among the included pregnancies, 2 had a spontaneous abortion, and 17 were further considered for maternal and perinatal outcomes. - Fig. 1 presents a flowchart of the cases included in the present study.

The mean age at transplantation was of $25.0 \pm 4.0$ years old, and the mean time interval until pregnancy was of $70.6 \pm 45.3$ months. The majority of women were white, and most of them lost their kidney function due to hypertension. Azathioprine, prednisone, and cyclosporine were the most used immunosuppressive drugs before pregnancy. The majority of women had their $1^{\text {st }}$ pregnancy after the transplantation. - Table 1 presents these data.

The most frequent complication during pregnancy was hypertension, which affected $11(64.7 \%)$ of the women

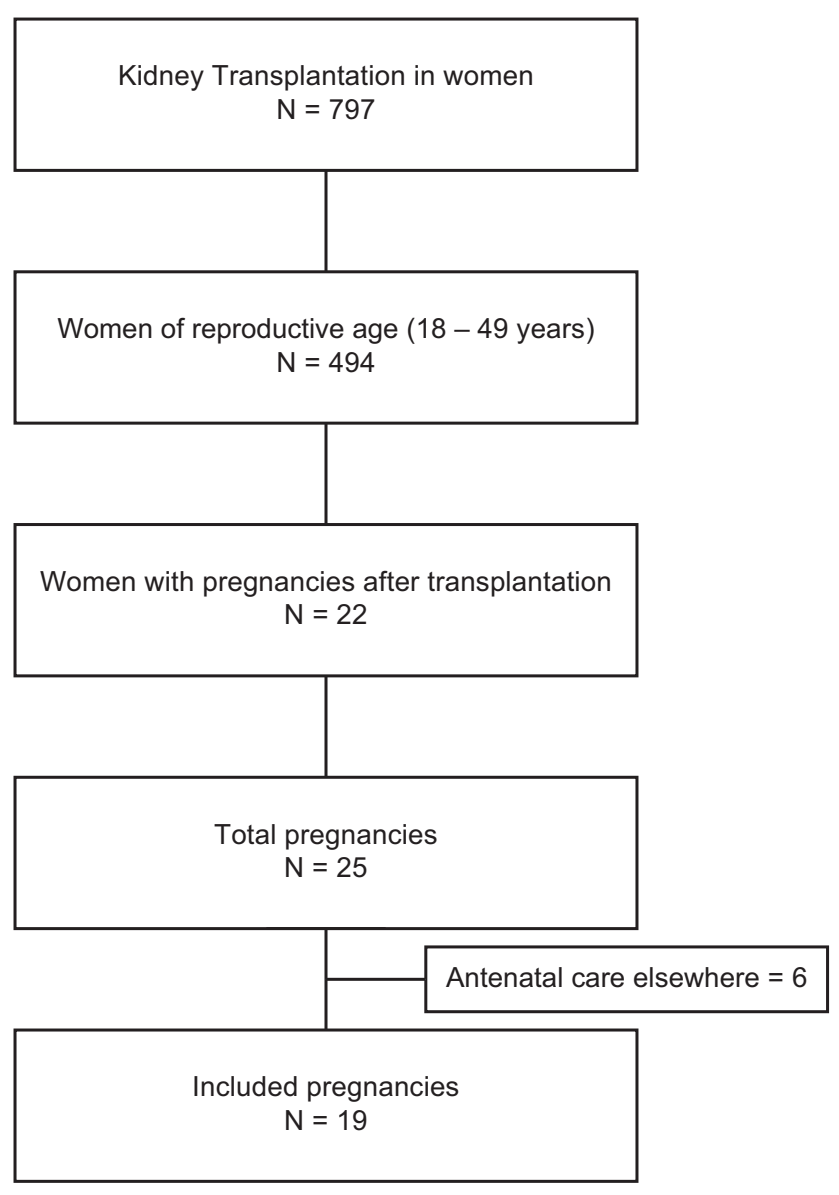

Fig. 1 Flowchart of inclusion.
Table 1 Sociodemographic characteristics of pregnant women with previous kidney transplant

\begin{tabular}{|c|c|}
\hline Variable & \\
\hline$n$ & 19 \\
\hline $\begin{array}{l}\text { Age at transplantation } \\
\text { (years old, mean } \pm S D \text { ) }\end{array}$ & $25.0 \pm 4.0$ \\
\hline \multicolumn{2}{|l|}{$\begin{array}{l}\text { Underlying cause of chronic } \\
\text { kdney disease }(n, \%)\end{array}$} \\
\hline Hypertension & $6(31.6)$ \\
\hline Chronic glomerulonephritis & $3(15.8)$ \\
\hline Chronic pyelonephritis & $3(15.8)$ \\
\hline Drug nephrotoxicity & $1(5.3)$ \\
\hline Unknown & $6(31.6)$ \\
\hline \multicolumn{2}{|l|}{ Skin color (n, \%) } \\
\hline White & $16(84.2)$ \\
\hline Non-white & $3(15.8)$ \\
\hline \multicolumn{2}{|l|}{$\begin{array}{l}\text { Prepregnancy immunosuppressive } \\
\text { drug }(n, \%)\end{array}$} \\
\hline Azathioprine & $18(94.7)$ \\
\hline Prednisone & $16(94.1)$ \\
\hline Cyclosporine & $14(82.3)$ \\
\hline Tacrolimus & $1(5.9)$ \\
\hline $\begin{array}{l}\text { Prepregnancy weight } \\
\text { (kilograms, mean } \pm \text { SD) }\end{array}$ & $64.5 \pm 12.7$ \\
\hline \multicolumn{2}{|l|}{ Parity (n, \%) } \\
\hline 1 & $9(47.4)$ \\
\hline 2 & $4(21.0)$ \\
\hline$\geq 3$ & $6(31.6)$ \\
\hline $\begin{array}{l}\text { Transplantation-to-pregnancy interval } \\
\text { (months, mean } \pm \text { SD) }\end{array}$ & $70.6 \pm 45.3$ \\
\hline
\end{tabular}

Abbreviation: SD, standard deviation.

followed-up in this analysis. Five (29.4\%) of them had preeclampsia, and $2(11.8 \%)$ with severe features (they received magnesium sulfate). Four (23.5\%) women were admitted to the intensive care unit (ICU), and 1 (5.9\%) needed dialysis temporarily during the postpartum period. Only 2 (11.8\%) of them had postpartum infection. Fetal growth restriction affected 4 (23.5\%) of these pregnancies. - Table 2 shows these data. Among the women included, only 1 presented graft failure, 7 years after the pregnancy.

- Table 3 presents data regarding delivery. Gestational age at delivery was $34.7 \pm 4$ weeks, and $47 \%$ of those pregnancies were preterm ( $<37$ weeks). A total of $88.2 \%$ of the women delivered by cesarean section, and maternal reasons justified the majority of the cesarean sections performed. The mean birthweight at delivery was $2,339 \pm 820 \mathrm{~g}$, and only 3 (17.6\%) babies were small for gestational age, and only 1 newborn had an Apgar score at 5 minute $<7$. Almost all $(14 ; 82.3 \%)$ of the women were using a contraceptive method postpartum; among them, definitive sterilization was chosen by 6 women, while long-term methods (levonorgestrel intrauterine system 
Table 2 Pregnancy complications of pregnant women with previous kidney transplantation

\begin{tabular}{|l|l|}
\hline Variable & $\boldsymbol{n}(\%)$ \\
\hline & $17^{\mathrm{a}}$ \\
\hline Complications during pregnancy (n, \%) & \\
\hline Hypertension $^{\mathrm{b}}$ & $11(64.7)$ \\
\hline Pre-eclampsia $^{(29.4)}$ \\
\hline Use of magnesium sulfate (severe features) & $2(11.8)$ \\
\hline Gestational diabetes & $1(5.9)$ \\
\hline Dialysis & \\
\hline Intensive care unit admission & $1(5.9)$ \\
\hline Fetal growth restriction & $4(23.5)$ \\
\hline Postpartum infection & $4(23.5)$ \\
\hline
\end{tabular}

A: Two pregnancies that ended as $1^{\text {st }}$ trimester miscarriage were excluded. B: Hypertension included chronic hypertension, gestational hypertension, and preeclampsia. C: In the postpartum period; no cases were reported during pregnancy.

and copper intrauterine device) and short-term methods (oral contraceptive or injectable progesterone) were chosen by 4 women each.

Renal function, measured by serum creatinine, remained stable during pregnancy, considering a first measurement during admission to antenatal care and another in the end of pregnancy or delivery (-Fig. 2). Systolic blood pressure upgraded significantly during pregnancy, while diastolic blood pressure did not differ in initial and delivery measures (-Table 4).

\section{Discussion}

Our study showed that pregnancies after kidney transplantation are rare events, with good perinatal and clinical outcomes. Hypertension was an important complication among the women followed in our study, with an important incidence of pre-eclampsia. This result may be due to the use of cyclo-
Table 3 Perinatal outcomes and postpartum contraception in women with pregnancy after kidney transplantation

\begin{tabular}{|l|l|}
\hline Variable & \\
\hline$n$ & $17^{\mathrm{a}}$ \\
\hline $\begin{array}{l}\text { Mean maternal age at delivery } \\
\text { (years old, mean } \pm \text { SD) }\end{array}$ & $30.5 \pm 4.0$ \\
\hline $\begin{array}{l}\text { Gestational age at delivery } \\
\text { (weeks, mean } \pm \text { SD) }\end{array}$ & $34.7 \pm 4.0$ \\
\hline Preterm delivery (n, \%) & $8(47.0)$ \\
\hline$<34$ weeks & 4 \\
\hline$\geq 34$ weeks & 4 \\
\hline Delivery route (n, \%) & $2(11.8)$ \\
\hline Vaginal & $15(88.2)$ \\
\hline Cesarean & 10 \\
\hline Maternal indication ${ }^{\text {b }}$ & 5 \\
\hline Fetal indication & \\
\hline Birthweight at delivery (grams, mean \pm SD) & $2339 \pm 820$ \\
\hline 5 minute Apgar score $\leq 7$ ( $n, \%)$ & $1(5.9)$ \\
\hline Small-for-gestational age $(n, \%)$ & $3(17.6)$ \\
\hline Postpartum contraception $(n, \%)$ & $14(82.3)$ \\
\hline Definitive sterilization & $6(35.3)$ \\
\hline Levonorgestrel intrauterine system & $3(17.6)$ \\
\hline Oral contraceptive & $3(17.6)$ \\
\hline Copper intrauterine device & $1(5.9)$ \\
\hline Injectable progesterone & $1(5.9)$ \\
\hline
\end{tabular}

Abbreviation: SD, standard deviation.

A: Two pregnancies that ended as $1^{\text {st }}$ trimester miscarriage were excluded. B: Maternal indications included: maternal choice, worsening of maternal conditions, unfavorable pelvis, cephalic-pelvic disproportion. C: Fetal indications included acute or chronic fetal distress.

sporin as a maintenance immunosuppressive therapy in the majority of the transplant recipients evaluated. Previous studies have shown a rate $>$ between 60 and $70 \%$ of maternal complications such as pre-eclampsia and hypertension in

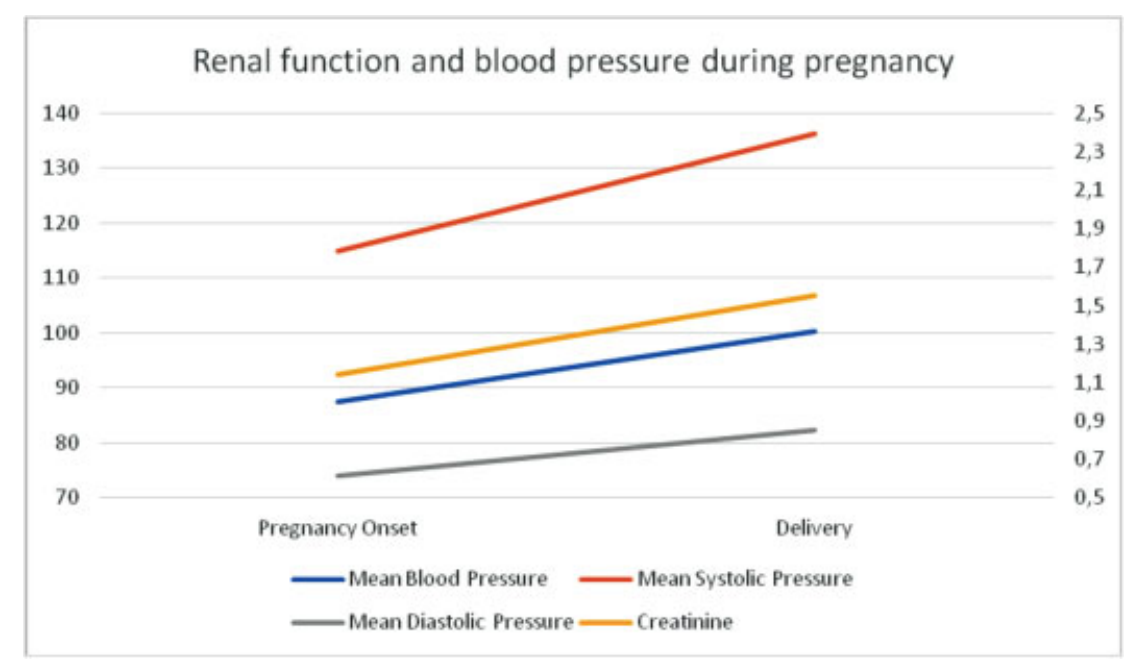

Fig. 2 Renal function and blood pressure during pregnancy. 
Table 4 Renal function and blood pressure during pregnancy

\begin{tabular}{|l|l|l|l|}
\hline & $\begin{array}{l}\text { Pregnancy - } \text { 1 }^{\text {st }} \\
\text { Evaluation }^{\text {A }}\end{array}$ & $\begin{array}{l}\text { Admission } \\
\text { for birth }\end{array}$ & p-value \\
\hline $\begin{array}{l}\text { Creatinine } \\
\text { (mg/dL) }\end{array}$ & $1.14 \pm 0.84$ & $1.55 \pm 1.37$ & 0.3 \\
\hline $\begin{array}{l}\text { Mean blood } \\
\text { pressure } \\
\text { (mmHg) }\end{array}$ & $87.5 \pm 13.7$ & $100.3 \pm 16.0$ & 0.02 \\
\hline $\begin{array}{l}\text { Mean systolic } \\
\text { pressure } \\
\text { (mmHg) }\end{array}$ & $114.8 \pm 16.1$ & $136.2 \pm 21.9$ & $<0.01$ \\
\hline $\begin{array}{l}\text { Mean diastolic } \\
\text { pressure } \\
\text { (mmHg) }\end{array}$ & $73.9 \pm 13.1$ & $82.4 \pm 14.1$ & 0.08 \\
\hline
\end{tabular}

A: In the $1^{\text {st }}$ trimester.

renal transplant recipients receiving cyclosporin, similar to the rates observed in our study. In addition, hypertension was the main etiology of chronic kidney disease in our cohort, which could be related to the elevated incidence of hypertension and pre-eclampsia during the follow-up. The prolonged use or high dose of glucocorticoids could also be associated with the onset or with the worsening of hypertension in this series. The side effects of azathioprine, another immunosuppressive drug frequently used in our series, at doses used in kidney transplantation, include gastrointestinal intolerance, bone marrow suppression, liver function abnormalities, and infections, with no effect on blood pressure. Also, in this series, teratogenic drugs such as mycophenolate or mammalian target of rapamycin (mTOR) inhibitors were avoided or discontinued in fertile women who expressed the desire of pregnancy, and were replaced by azathioprine, as a transplant unit routine. ${ }^{11}$

Spontaneous abortion is a known concern among women who use immunosuppressant therapy due to the effect of the drugs used. In our cohort, only two abortions were reported, a result similar to those of other reports, ${ }^{12,13}$ and we had no cases of fetal malformation, probably due to the adequacy of the therapeutic scheme adopted toward women planning pregnancy. The placental concentration of cyclosporin used to be between 5 and 10 times higher than that found in maternal blood, with the fetus blood level about half than that found in the mother. Because of this, cyclosporin does not lead to an increased risk for fetal malformations after exposure. Azathioprine is mutagenic, but its teratogenicity was demonstrated in animal studies at doses much higher than those used in kidney transplantation. Glucocorticoid teratogenicity was excluded by previous studies even for intravenous high doses. ${ }^{11}$ Currently, tacrolimus is the first-choice drug for immunosuppression after kidney transplantation; however, until 2004, cyclosporin was the first-line immunosuppressive drug in our service. Patients with stable allograft function were kept with that drug. ${ }^{14}$

Reproductive-aged women who received a kidney graft may desire pregnancy after the improvement of their quality of life and the normalization of their reproductive cycles, even knowing this may be a high-risk pregnancy. ${ }^{15}$ Medical morbidities, as many other social conditions, affects the reproductive cycle of women, including pregnancy, delivery and the postpartum period, and many of those are not modifiable conditions. ${ }^{16}$ Having a transplanted kidney is one of those conditions, and a multidisciplinary approach to pregnancy, including nephrologists and obstetricians, may improve the experience of the women during pregnancy and reduce obstetrical and clinical complications during pregnancy, with timely diagnoses and treatment.

Hypertensive disorders are a key concern during the antenatal care of women after kidney transplantation, since it can be a life-threatening condition during pregnancy and may affect allograft function. Pre-eclampsia was a common complication in our cohort, as it was in other previous reports. ${ }^{12,13,17}$ Prescribing low-dose aspirin and calcium supplementation, with an intensive surveillance of blood pressure has been the standardized follow-up of these women in our center. Also, we believe that a frequent assessment of the renal function using serum creatinine and 24-hour proteinuria is mandatory in these cases.

Our cesarean rates were high, mostly due to the worsening of maternal conditions. While another two Brazilian studies seem to have lower cesarean section rates, ${ }^{17,18}$ a most recent European study presented rates similar to ours. ${ }^{19}$ Having previous kidney transplantation is not a reason to perform a cesarean section, and induction of vaginal delivery is possible in the majority of cases. Despite that, our perinatal outcomes were satisfactory, proving that close surveillance of these women, during pregnancy and delivery, is fundamental.

Counseling about contraception to these women is very important, and our data show that the majority used longterm methods postpartum. Definitive sterilization, after providing qualified information, may be an option; however, intrauterine reversible devices are also a safe intervention. ${ }^{20}$

We present here the experience of the institution in the last 20 years with kidney transplant and pregnancy. The total number of cases seems low; however, they are not, for a single center, and the results on maternal and perinatal outcomes are good, with an integrated multidisciplinary approach. Unfortunately, we do not have long-term followup postpartum or data on pregnancy desire and planning among transplantation cases.

\section{Conclusion}

Pregnancy after kidney transplantation is a rare event. In our case series, the rates of spontaneous abortion were similar to those of the general population, the main complications were due to hypertensive disorders, with an important occurrence of prematurity and high rates of cesarean deliveries. Pregnancy did not seem to affect graft function; however, the increase in blood pressure may have long-term consequences and calls for continuous follow-up. A multidisciplinary team and regular evaluation of pregnancy and transplantation-related complications are the key for a good care.

\section{Contributors}

Mariano S. contributed by collecting data and writing the first draft; Guida J. P. S. contributed by performing the statistical analysis and writing the first draft; Sousa M. V. 
contributed by collecting data and writing the first draft; Parpinelli M. A. and Surita F. G. had the original idea for the present study, supervised the data collection and reviewed the first draft; Mazzali M. and Costa M. L. coordinated the present study, reviewed the medical charts and reviewed the first draft.

\section{Conflicts of Interests}

The authors have no conflicts of interests to declare.

\section{References}

1 Sharaf El Din UA, Salem MM, Abdulazim DO. Stop chronic kidney disease progression: Time is approaching. World J Nephrol 2016; 5(03):258-273. Doi: 10.5527/wjn.v5.i3.258

2 Sesso RC, Lopes AA, Thomé FS, Lugon JR, Martins CT. Brazilian chronic dialysis survey 2016. J Bras Nefrol 2017;39(03):261-266. Doi: 10.5935/0101-2800.20170049

3 Registro Brasileiro de Transplantes. 2018; 24(3). São Paulo, SP: Associação Brasileira de Transplante de Órgãos. http://www.abto. org.br/abtov03/Upload/file/RBT/2018/rbt2018-let-3t.pdf. Accessed 16 Jan, 2019.

4 Nadeau-Fredette AC, Hladunewich M, Hui D, Keunen J, Chan CT. End-stage renal disease and pregnancy. Adv Chronic Kidney Dis 2013;20(03):246-252. Doi: 10.1053/j.ackd.2013.01.010

5 Hou S. Pregnancy in renal transplant recipients. Adv Chronic Kidney Dis 2013;20(03):253-259. Doi: 10.1053/j.ackd.2013.01.011

6 Başaran O, Emiroğlu R, Seçme S, Moray G, Haberal M. Pregnancy and renal transplantation. Transplant Proc 2004;36(01):122-124. Doi: $10.1016 /$ j.transproceed.2003.11.011

7 Rocha A, Cardoso A, Malheiro J, et al. Pregnancy after kidney transplantation: graft, mother, and newborn complications. Transplant Proc 2013;45(03):1088-1091. Doi: 10.1016/j.transproceed.2013.02.006

8 Blume C, Pischke S, von Versen-Höynck F, Günter HH, Gross MM. Pregnancies in liver and kidney transplant recipients: a review of the current literature and recommendation. Best Pract Res Clin Obstet Gynaecol 2014;28(08):1123-1136. Doi: 10.1016/j.bpob gyn.2014.07.021
9 Shah S, Verma P. Overview of pregnancy in renal transplant patients. Int J Nephrol 2016;2016:4539342. Doi: 10.1155/2016/4539342

10 von Elm E, Altman DG, Egger M, Pocock SJ, Gøtzsche PC, Vandenbroucke JP; STROBE Initiative. The Strengthening the Reporting of Observational Studies in Epidemiology (STROBE) statement: guidelines for reporting observational studies. PLoS Med 2007; 4(10):e296. Doi: 10.1371/journal.pmed.0040296

11 Colla L, Diena D, Rossetti M, et al. Immunosuppression in pregnant women with renal disease: review of the latest evidence in the biologics era. J Nephrol 2018;31(03):361-383. Doi: 10.1007/ s40620-018-0477-3

12 Erman Akar M, Ozekinci M, Sanhal C, et al. A retrospective analysis of pregnancy outcomes after kidney transplantation in a single center. Gynecol Obstet Invest 2015;79(01):13-18. Doi: 10.1159/000365815

13 Perales-Puchalt A, Vila Vives JM, López Montes J, Diago Almela VJ, Perales A. Pregnancy outcomes after kidney transplantation-immunosuppressive therapy comparison. J Matern Fetal Neonatal Med 2012;25(08):1363-1366. Doi: 10.3109/14767058.2011.634461

14 Guerra AA Junior, Acúrcio FA, Andrade EI, et al. Cad Saude Publica 2010;26:163-174. Doi: 10.1590/S0102-311 × 2010000100017

15 Josephson MA, McKay DB. Women and transplantation: fertility, sexuality, pregnancy, contraception. Adv Chronic Kidney Dis 2013;20(05):433-440. Doi: 10.1053/j.ackd.2013.06.005

16 Filippi V, Chou D, Barreix M, Say L; the WHO Maternal Morbidity Working Group. A new conceptual framework for maternal morbidity. Int J Gynaecol Obstet 2018;141:4-9. Doi: 10.1002/ijgo.12463

17 Candido C, Cristelli MP, Fernandes AR, et al. Pregnancy after kidney transplantation: high rates of maternal complications. J Bras Nefrol 2016;38(04):421-426. Doi: 10.5935/0101-2800.20160067

18 Oliveira LG, Sass N, Sato JL, Ozaki KS, Medina Pestana JO. Pregnancy after renal transplantation-a five-yr single-center experience. Clin Transplant 2007;21(03):301-304. Doi: 10.1111/j.13990012.2006.00627.x

19 Madej A, Mazanowska N, Szpotańska-Sikorska M, et al. Delivery method in patients after liver or kidney transplantation. Transplant Proc 2018;50(07):2150-2153. Doi: 10.1016/j.transproceed. 2018.05.003

20 Juliato CRT, Stahlschmidt P, Fernandes A, Monteiro I, Bahamondes L. A case series on the use of levonorgestrel $52 \mathrm{mg}$ intrauterine system after organ transplant. Contraception 2018;98(03): 252-254. Doi: 10.1016/j.contraception.2018.04.017 